\title{
Winter Birds at Meadow Lake
}

\section{Frank Roy}

MEADOW LAKE, a town of some 2,500 people in the far northwest corner of Saskatchewan, is the most northerly large community in Saskatchewan. Situated in an expansive flat which has been largely cleared of all its former timber, it is an island of farmland surrounded by a dense cover of forest. To the south of the town is the height of land. All waters to the north of this height of land flow to the Churchill; to the south they empty eventually into the North Saskatchewan.

While Meadow Lake itself is almost treeless, it is but a matter of 6 to 8 miles in any direction before one encounters substantial wooded plots. Meadow Lake, from which the town derives its name, is a large, shallow body of water about one mile east of town. Within a 40 -mile radius there are several other typical northern lakes. These include Green Lake, prominent in the early history of the Hudson's Bay Company; Loon Lake, a commercial resort; Grieg, Flotten and Waterhen Lakes. Several rivers course through the area, including the Meadow, the Loon, the Waterhen and the Beaver. The latter is a tributary of the Churchill. Naturally, we in town here, see a great many woodland birds because of our proximity to the forests and lakes which have been mentioned above.

The season of 1951-52 has been interesting for winter visitors. February, an unusually mild month, brought more visitors than we have had in any of the last three years. Almost every day a person can go out and hear the familiar reedy whistle of Bohemian Waxwings as they sit perched in a nearby berry tree or maple. Occasionally a flock of Evening Grosbeaks visits us, but they are not nearly as familiar as their showy relatives, the Pine Grosbeaks. Pine Grosbeaks, in flocks of 5 to 75 , canvass every tree and bush in Meadow Lake from January through March.

Other visitors which come into town from the forests include the Blue Jays-and surprisingly enough, they are not the friendly inquisitive birds which Mrs. Priestly described when she chose the name "Blue Jay" for our magazine. In Meadow Lake, at least, they are shy, retiring creatures which never allow an approach as close as one would like. How did Nature ever imprison a bit of the sky's blue in their plumage?

Canada Jays very rarely leave the confines of the woods, and not more than two or three will be observed all winter within the town limits. Redpolls, too, are spasmodic visitors. Last week we welcomed several hundred of them. This week there isn't one to be heard or seen. Snow Buntings often fly over town singly or in pairs, but for fiocks we have to go out on the highways in the woods. Flocks of several hundred will settle on the roads which in many cases are the only open spots for miles around.

Several times this winter, one of my students has mentioned to me: "Say, did you see those crows today? I saw them and they're really big." The "crows" which they see are Ravens. This year they have come very close to town, and if one is lucky he may see 10 to 12 of these "big crows" in an afternoon's drive near town. On the same drive he may see the tracks of Sharp-tailed Grouse, Hungarian Partridge and Ruffed Grouse in the grain fields and forest borders away from town. None of these birds are numerous, since this community is very "trigger-happy" every autumn. A visiting cousin of the grouse and partridge is the Willow Ptarmigan which comes south when it's really cold. This winter I haven't spied one of these snow white fowl, but three years back they even came into the gardens at the edge of town.

A drive out to the Saint Cyr Hills to the northwest of town always reveals a number of magpies. These birds are typical of the hills and coulees of the region. Hairy and Downy Woodpeckers are found throughout the area and once in a while the observers' heart skips a beat when he sees a Pileated Woodpecker. The latest specimen was seen at Loon Lake, 40 miles southeast of Meadow Lake. Two other birds should be mentioned in any list of our northern birds. These are the Snowy and Horned Owls. 
One Snowy Owl was shot here last fall, long before the snow came. Perhaps he was a harbinger of that extended cold snap we had during December and January.

And finaliy, the Chickadee, that merry little chirper which is always around to brighten our spirits even on the coldest January morning. To me, they seem to be a northern compensation for the noisy English Sparrow which they superficially resemble. Is there anyone who would not gladly exchange twenty sparrows for one of those chickadees?

Well, it won't be long before the first notes of the Horned Lark come. floating down to us from leaden March skies. Once again we will be eagerly anticipating the first Pintail, the first Meadow Lark, the first Mountain Bluebird. Who among us does not thrill to the age-old, ever-new rhythm of the seasons with its familiar pattern which still permits of intriguing surprises? Up here on the northern fringe of settlement, we'll be waiting, watching and listening for the first spring arrivals.

\section{"Today I Saw The Dragon-Fly Come From The Wells Where He Did Lie"}

Hugh McLaughlin, Lewvan

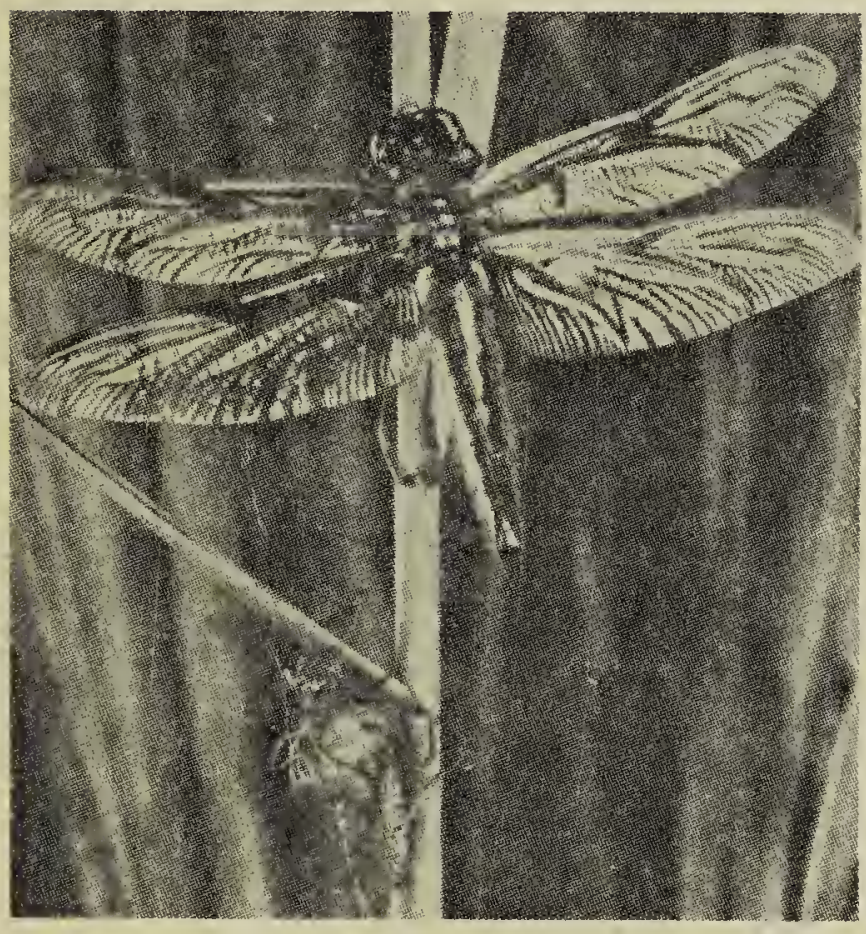

NE spring morning in the early hours while preparing the tractor for work, and noting that the contents of the radiator were down, I sought water at the creek to replenish it. While bending over grass and weeds to fill my pail, I was treated to an assembly line view of the emergence of a dragonfly nymph-a small compressed aquatic insect-a veritable submarine-into the greatly enlarged gauzy-winged adult dragonfly; free flier of the air and sky - a versatile airplane.

The first nymph had but lately emerged from the water and had fastened itself several inches above the surface to a reed. The skin had parted at the back of the thorax and the new creature was literally tumbling backwards out of its skin. The second insect was hanging in stillness to its cast nymphal form, waiting for its body to harden and for tiny sprouts to unroll and spread -waiting for its wings.

The nymphal forms remain clinging to the reeds long after the adult dragonfly takes off-until rain or mechanical disturbances brushes them off. The third insect was experimentally raising and lowering new wings, testing and hardening for its new life. Glancing back again to the first one, the abdomen had grown considerably. It still hung backward in a circle and would soon be able to grasp the reed below, free itself from the limited confines of its aquatic form and await its wings also. However, the demands that sent me here still awaited-this whole process would require an hour or more-so filling the pail I departed

In the aquarium there were several damsel-fly nymphs which are quite like small editions of the dragonfly, although the wings, when at rest, lie together in line with the abdomen instead of at right angles as are the wings of the larger insect. The nymphs have three leaf-like gills attached to the end of the abdomen, which they gently wave back and forth when resting-no doubt to aerate the gills.

One nymph seemed to have grown tired of the water, hovered near the surface and readily climbed out on my finger. As we were leaving the (Continued on page 25) 